\title{
The in vitro and in vivo investigation of biological activities and phenolic analysis of Helichrysum plicatum subsp. plicatum
}

\author{
Turgut Taşkın ${ }^{\oplus *}$, Tuğba Gezmiş², Muhammet Emin Çam³ ${ }^{3}$ Duygu Taşkın \\ Berna Özbek Çelik ${ }^{5}$ İsmail Şenkardeş ${ }^{6}$, Sevda Süzgeç-Selçuk ${ }^{7}$
}

\begin{abstract}
${ }^{I}$ Department of Pharmacognosy, Faculty of Pharmacy, Marmara University, Istanbul, Turkey, ${ }^{2}$ Aysu Pharmacy, Istanbul, Turkey, ${ }^{3}$ Department of Pharmacology, Faculty of Pharmacy, Marmara University, Istanbul, Turkey, ${ }^{4}$ Department of Analytical Chemistry, Faculty of Pharmacy, University of Health Sciences, Istanbul, Turkey, ${ }^{5}$ Department of Pharmaceutical Microbiology, Faculty of Pharmacy, Istanbul University, Istanbul, Turkey, ${ }^{6}$ Department of Pharmaceutical Botany, Faculty of Pharmacy, Marmara University, Istanbul, Turkey, ${ }^{7}$ Department of Pharmacognosy, Faculty of Pharmacy, Istanbul University, Istanbul, Turkey
\end{abstract}

\begin{abstract}
In Turkey, Helichrysum genus is represented by 26 taxa belonging to 20 species in Turkish flora of which 14 ones are endemic to Turkey. The aerial parts of Helichrysum plicatum subsp. plicatum are used kidney stones, kidney and stomach ailments. The extraction procedures and solvents are important step in processing of bioactive constituents from the plant materials. Therefore, the aim of this study was to evaluate in vitro antioxidant, antimicrobial, anti-urease, anticholinesterase and in vivo antiinflammatory activities of Helichrysum plicatum subsp. plicatum different extracts. In addition, the phenolic characterization of the Soxhlet and maceration methanol extracts which showed significant antioxidant, anti-urease, antimicrobial, anti-inflammatory and anticholinesterase activities were performed by HPLC-DAD and LC-MS/MS. In the present study, the Soxhlet methanol extract exhibited strong antioxidant, antimicrobial and anticholinesterase activities than other extracts. The maceration methanol extract showed the strongest anti-urease activity. The Soxhlet methanol and maceration methanol extracts showed in vivo anti-inflammatory activities very close to each other. As a result of this study, chlorogenic acid, dicaffeoylquinic acid, luteolin, luteolin-7-O-glucoside, naringenin- $O$-hexoside and isoquercitrin compounds were analysed in plant. Therefore, it is thought that methanol extracts can be used as a natural source in the future for food and pharmaceutical industries.
\end{abstract}

Keywords: Helichrysum plicatum subsp. plicatum. Anti-inflammatory. Anti-urease. Anticholinesterase. HPLC-DAD-MS.

\section{INTRODUCTION}

Natural antioxidants are more readily acceptable than synthetic antioxidants. Recently, much focus has been given to the involvement of active oxygen and free radicals in aging and disease processes like heart disease, inflammation, arthritis, immune system impairment and cancer. Oxidative stress is defined by an imbalance between increased levels of reactive oxygen species (ROS) and a low activity of antioxidant mechanisms. An increased oxidative stress can induce damage to the cellular structure and potentially destroy tissues.

\footnotetext{
*Correspondence: T. Taşkın. Department of Pharmacognosy, Faculty of Pharmacy, Marmara University, Istanbul, Turkey. E-mail: turguttaskin@marmara.edu.tr
}

Antioxidants terminate ROS attacks and thus help prevent the diseases and health problems. There is a general trend to search safe and effective antioxidants from natural sources (Denys et al., 2013). Inflammation is the first response of body to infection or injury and is critical for both innate and adaptive immunity. It can be considered as part of the complex biological response of vascular tissues to harmful stimuli such as pathogens, damaged cells or irritans. The search for natural compounds and phytoconstituents that are able to interfere with these mechanisms by preventing a prolonged inflammation could be useful for human health (Parimelazhagan, 2016). The selection and extraction method of solvent for the extraction of plant material to determine the potential activity of the extract is one of the most important 
factors, since the solvent polarity and extraction method determines that compounds will be extracted or not. Thus, in many cases of newly studied plants, various extracts are prepared using different extraction methods and solvents (Azwanida, 2015).

The genus Helichrysum (Asteraceae) is represented by approximately 500 species in the World. In Turkey, Helichrysum genus is represented by 26 taxa belonging to 20 species in Turkish flora of which 14 ones are endemic for Turkey (Davis, 1975; Davis et al., 1988; Kupicha, 1975; Erik, 2000). Various Helichrysum species have been widely used as folk remedy in Turkish folk medicine for diuretic and anti-asthmatic properties as well as againts kidney stones and stomache as decoction (Aslan et al., 2007; Suzgec et al., 2005; Selcuk, Birteksoz, 2011). Helichrysum plicatum subsp. plicatum species are known as sarıçiçek and aerial parts of plant are used kidney stones, kidney and stomach ailments (infusion and decoction) and depreciatory (as tea) (Yeşil, Akalın, 2009). Helichrysum plicatum DC. subsp. plicatum is known with a rich flavonoids content, comprising $4.83 \%$ flavonoids such as helichrysins A and $\mathrm{B}$, apigenin, naringenin, isoastragalin and isosalopurposide (Demir et al., 2009). The best of our knowledge, there is no reports on the effect of extraction methods on the biological activity of this plant. In addition to this, although the plant is used as tea, there is no study of the plants' anti- urease, anticholinesterase activity, and analysis of major phenolic compounds with responsible for the activity. Therefore, the aim of this study was to evaluate in vitro antioxidant, antimicrobial, anti-urease, anticholinesterase and in vivo anti-inflammatory activities of Helichrysum plicatum subsp. plicatum using a variety of extracts. And, the phenolic characterization of the Soxhlet and maceration methanol extracts, which showed the strongest biological activity were analyzed by HPLC-DAD and LC-MS/MS techniques.

\section{MATERIAL AND METHODS}

\section{Chemicals}

Folin Ciocalteu's phenol reagent, gallic acid, 2,4,6-tripyridyl-s-triazine, 2,2-diphenyl-1-picryl-hydrazyl $\left(\mathrm{DPPH}^{\circ}\right)$ and ascorbic acid were obtained from Sigma Chemical Co.. 2,2'-azino-bis(3-ethylbenzothiazoline6-sulfonate) and butylated hydroxytoluene was sourced from Fluka. All other reagents were of analytical grade.

\section{Plant material and preparation of plant extracts}

H. plicatum subsp. plicatum aerial parts were collected in 2016 from Uludağ-Bursa, Turkey and was authenticated by Asst. Prof. Dr. Ismail Senkardes. A voucher specimen (MARE-18080) was deposited at the herbarium of the Faculty of Pharmacy, Marmara University for future reference. The plant aerial parts was dried in shade $\left(25^{\circ} \mathrm{C}\right)$ and ground in a mechanic grinder (Renas, RBT1250) to fine powder. The powdered sample $(50 \mathrm{~g})$ was extracted with organic solvents $(500 \mathrm{~mL})$ such as petroleum ether (HPE), chloroform (HC) and methanol (HSM) using the Soxhlet method respectively until colorless. In addition, 15 gram of powdered sample was extracted with direct methanol $(500 \mathrm{~mL})(\mathrm{HMM})$ solvent using the maceration method until the colorless. The four different extracts were concentrated by rotary vacuum evaporator. All the extracts obtained were stored at $-20^{\circ} \mathrm{C}$ for future analysis.

\section{Extract yield percentage and total flavonoid contents}

The extraction yield was calculated to determine the effect of the solvents in order to extract the active compounds from the plant material (Murugan, Parimelazhagan, 2014).

The percentage yield was obtained using this formula:

$$
\% \text { extract yield }=\mathrm{A}_{2}-\mathrm{A}_{1} / \mathrm{A}_{0} \times 100
$$

where $A_{2}$ is the weight of the extract and the container, $A_{1}$ is the weight of the container alone and $\mathrm{A}_{0}$ is the weight of the initial dried sample.

The total flavonoid contents of the extract was determined using the aluminium chloride assay (Samatha et al., 2012). $0.5 \mathrm{~mL}$ of extract solution was taken in different test tubes then $2 \mathrm{~mL}$ of distilled water was added. Next step was followed by the addition of $0.15 \mathrm{~mL}$ of sodium nitrite $\left(5 \% \mathrm{NaNO}_{2}, \mathrm{w} / \mathrm{v}\right)$ and allowed to stand for $6 \mathrm{~min}$. Then $0.15 \mathrm{~mL}$ of aluminium trichloride $\left(10 \% \mathrm{AlCl}_{3}\right)$ was added and incubated for $6 \mathrm{~min}$, followed by the addition of $2 \mathrm{~mL}$ of sodium hydroxide $(\mathrm{NaOH}, 4 \%$ $\mathrm{w} / \mathrm{v}$ ) and volume was equal to $5 \mathrm{~mL}$ with distilled water. The mixture was allowed to stand at ambient temperature for 15 minutes. Then, the absorbance was measured at $510 \mathrm{~nm}$ against a reagent blank. Total flavonoid contents were expressed as quercetin equivalents in milligram per milligram of extract (mg QuE /mg extract) $\left(R^{2}=0.9940\right)$.

\section{In vitro evaluation of biological activity}

\section{DPPH radical scavenging activity}

The ability of free radical scavenging of four different extracts was determined using the DPPH method. 
Briefly, $240 \mu \mathrm{L}$ of DPPH solution $(0.1 \mathrm{mM})$ was added to $10 \mu \mathrm{L}$ of extracts prepared at different concentrations $(5 \mathrm{mg} / \mathrm{mL}-0.5 \mathrm{mg} / \mathrm{mL})$. Then the mixture was allowed to stand at room temperature for $30 \mathrm{~min}$. The absorbance of the mixture was measured against the reference using a micro plate reader at $517 \mathrm{~nm}$. The experiment was repeated three times and the results obtained in the experiment were given as $\mathrm{IC}_{50}=\mathrm{mg} / \mathrm{mL}$ (Wei et al., 2010).

\section{Trolox equivalent antioxidant activity}

Briefly, $40 \mu \mathrm{L}$ of four different extracts $(5 \mathrm{mg} / \mathrm{mL}$ $0.5 \mathrm{mg} / \mathrm{mL}$ ) prepared from plant material, $3960 \mu \mathrm{L}$ of $\mathrm{ABTS}^{\circ+}$ working solution were combined. The absorbance of the mixture was measured against the reference at $734 \mathrm{~nm}$ for $6 \mathrm{~min}$. The standard curve was prepared using trolox and the data obtained in this study were expressed as $\mathrm{mM}$ trolox/mg extract (Re et al., 1999).

\section{Ferric reducing/antioxidant power (FRAP) assay}

The ability of ferric reducing of different extracts ( $5 \mathrm{mg} / \mathrm{mL}-0.5 \mathrm{mg} / \mathrm{mL}$ ) was evaluated using the FRAP method. Briefly, $3.8 \mathrm{~mL}$ of FRAP reagent was mixed with $0.2 \mathrm{~mL}$ of extract and the absorbance of the mixture was measured against the reference at $593 \mathrm{~nm}$ after $4 \mathrm{~min}$. The standard curve was prepared using $\mathrm{FeSO}_{4} \cdot 7 \mathrm{H}_{2} \mathrm{O}$ and FRAP values of the extracts were expressed as a $\mathrm{mM} \mathrm{Fe}{ }^{2+} / \mathrm{mg}$ extract (Benzie, Strain, 1996).

\section{Anti-urease activity}

Briefly, $500 \mu \mathrm{L}$ of urease enzyme was added to $100 \mu \mathrm{L}$ of the working solutions and incubated at $37{ }^{\circ} \mathrm{C}$ for $30 \mathrm{~min}$. in the incubator. Then, $1100 \mu \mathrm{L}$ of urea was placed in this mixture and the mixture was incubated for $30 \mathrm{~min}$. at $37^{\circ} \mathrm{C}$ in the incubator. $\mathrm{R}_{1}(1 \%$ phenol, $0.005 \%$ sodium nitroprusside $)$ and $\mathrm{R}_{2}(0.5 \% \mathrm{NaOH}, 0.1 \%$ sodium hypochlorite) reagents were added respectively to the mixture. The mixture was incubated for $2 \mathrm{~h}$. in the incubator $\left(37^{\circ} \mathrm{C}\right)$ and then the absorbance of mixture was read at $635 \mathrm{~nm}$ against the reference (Ghous et al., 2010).

\section{Anticholinesterase activity of extracts}

Inhibition of cholinesterases was evaluated using a 96-well microplate reader based on the method of Ellman et al. (1961) with some modifications. All reagent solutions (daily) were prepared using Tris- $\mathrm{HCl}$ buffer (50 mM, pH 8.0). Briefly, $20 \mu \mathrm{L}$ of AChE solution were mixed with $20 \mu \mathrm{L}$ of the sample and $40 \mu \mathrm{L}$ of Tris- $\mathrm{HCl}$ buffer and the mixture was left at room temperature $\left(25^{\circ} \mathrm{C}\right.$ ) for $10 \mathrm{~min}$. Then, $20 \mu \mathrm{L}$ of ATChI $(50 \mathrm{mM})$ was added the mixture and the mixture was incubated at $25^{\circ} \mathrm{C}$ for $5 \mathrm{~min}$. Then, $100 \mu \mathrm{L}$ of $20 \mathrm{mM}$ DTNB (containing $1 \mathrm{M}$
$\mathrm{NaCl}$ and $0.2 \mathrm{M} \mathrm{MgCl}_{2} \cdot 6 \mathrm{H}_{2} \mathrm{O}$ ) was added in the mixture and the absorbance of mixture was measured at $412 \mathrm{~nm}$ against the reference. The experiments were performed in triplicate in each case. Galantamine was used as reference (Ellman et al., 1961).

\section{Antimicrobial activity}

In this study, the in vitro antimicrobial activities of different extracts were studied using microdilution method as recommended by Clinical and Laboratory Standards Institute (CLSI) (CLSI, 2006; CLSI, 2000; Perez, Pauli, Bazerque, 1990).

\section{Test microorganisms}

Staphylococcus aureus ATCC 6538, Staphylococcus epidermidis ATCC 12228, Escherichia coli ATCC 8739, Pseudomonas aeruginosa ATCC 27853, Proteus mirabilis ATCC 14153, Klebsiella pneumoniae ATCC 4352, Candida albicans ATCC 10231, and MRSA.

\section{In vivo evaluation of biological activity}

\section{Anti-inflammatory activity}

Paw edema was induced in Sprague-Dawley rats by sub-plantar injection of $0.1 \mathrm{~mL}$ of $1 \%(\mathrm{w} / \mathrm{v})$ carrageenan in saline in the right paw. The different groups were treated orally with maceration methanol (HMM) and Soxhlet methanol extract (HSM) of $H$. plicatum subsp. plicatum $(250 \mathrm{mg} / \mathrm{kg}$, p.o.), indomethacin ( $5 \mathrm{mg} / \mathrm{kg}$, p.o.) and saline $(10 \mathrm{~mL} / \mathrm{kg}$, p.o.) $60 \mathrm{~min}$. before the administration of carrageenan (Sezik et al., 2010; Bayir et al., 2011). The volume of the edema development and its duration were determined for 4 hours using plethysmometer 37140 (UgoBasile, Italy). The inhibitory activity was calculated according to the formula: $\%$ Inhibition $=$ [(Vt-Vo) control - (Vt-Vo)]/[(Vt-Vo) control] x 100. Where $\mathrm{Vt}$ is the paw volume at time t, Vo is the paw volume before carrageenan injection, $(\mathrm{Vt}-\mathrm{Vo})$ is edema in paw after time $t$. The study was approved by Marmara University, Animal Experiments Local Ethics Committee (MÜHDEK-58.2017.mar).

\section{Analysis of phenolic compounds}

The active phenolic compounds in methanol extracts with strong biological activity were identified by HPLC-DAD based on comparison on-line ultraviolet absorption spectrum data and retention times acquired with authentic standards (Halpine, 1996). After that, they were confirmed by liquid chromatography with quadrupole time-of-flight mass spectrometry using targeted MS/MS 
techniques with accurate mass measurement. Phenolic compounds were identified and characterized by comparing maximum UV absorptions, HPLC retention time and MS/MS of target peaks in the extracts with the standards. Chromatographic peaks for phenolic compounds were selected by using the theoretical $[\mathrm{M}-\mathrm{H}]^{-}$ as precursor ion. MS/MS analysis of phenolic compounds was carried out in negative mode using electrospray ionization.

\section{Statistical analysis}

The results of the antioxidant and anti-urease experiments were analyzed by the Graphpad Prism 5 program. The data obtained from anti-inflammatory activity were analyzed by PASW Statistics.

\section{RESULTS AND DISCUSSION}

\section{In vitro evaluation of biological activity}

\section{Extract yield percentage and total flavonoid contents}

The total flavonoid contents and yield percentage of different extracts were analysed and presented in Table I. The results from the present study showed that the total flavonoid contents in Soxhlet methanol extract higher than other extracts. The petroleum ether extract had the lowest total flavonoid contents. When the yields percentage of the different extracts were compared, maceration methanol extract found to have higher recovery over other extracts.

TABLE I - Extract yield percentage and total flavonoid contents of $H$. plicatum subsp. plicatum

\begin{tabular}{lcc}
\hline & $\begin{array}{c}\text { Total flavonoid } \\
\text { (mgQUE/mg extract) }\end{array}$ & $\begin{array}{c}\text { Extract yield } \\
\mathbf{( \% )}\end{array}$ \\
\hline HPE & $0.784 \pm 0.018^{\mathrm{a}}$ & $3.613^{\mathrm{a}}$ \\
$\mathrm{HC}$ & $1.776 \pm 0.211^{\mathrm{b}}$ & $1.556^{\mathrm{b}}$ \\
$\mathrm{HSM}$ & $2.261 \pm 0.075^{\mathrm{c}}$ & $11.995^{\mathrm{c}}$ \\
$\mathrm{HMM}$ & $1.72 \pm 0.031^{\mathrm{d}}$ & $18.685^{\mathrm{d}}$ \\
\hline
\end{tabular}

Values are mean of triplicate determination $(n=3) \pm$ standard deviation. Means with different superscripts ${ }^{(a-d)}$ are significantly different, $p<0.05$. QUE-Quercetin equivalents. HPE: Soxhlet petroleum ether extract; HC: Soxhlet chloroform extract HSM: Soxhlet methanol extract; HMM: Maceration methanol extract

\section{Antioxidant activity of extracts}

The antioxidant activities of different extracts were shown in Table II. The Soxhlet methanol $\left(\mathrm{IC}_{50}\right.$ : $0.11 \pm 0.009 \mathrm{mg} / \mathrm{mL})$ and maceration methanol $\left(\mathrm{IC}_{50}\right.$ : $0.115 \pm 0.008 \mathrm{mg} / \mathrm{mL}$ ) extracts exhibited the strongest free radical scavenging activity. The chloroform extract showed the lowest DPPH free radical scavenging activity. As shown in Table 2, the radical scavenging DPPH activities of all extracts showed lower than that of ascorbic acid $\left(\mathrm{IC}_{50}: 0.004 \pm 0.002 \mathrm{mg} / \mathrm{mL}\right)$.

The maceration methanol (46.19 $\mathrm{mM}$ trolox/mg extract), and Soxhlet methanol (44.26 mM trolox/mg extract) extracts showed stronger ABTS radical cation scavenging activity than other extracts. The chloroform extract had the lowest ABTS radical cation scavenging activity. In this study, when we compare the extraction techniques, it has been found that the extract obtained by Soxhlet and maceration from the sample showed strong DPPH and ABTS radical scavenging activity.

In this study, Soxhlet methanol $\left(14.46 \mathrm{mM} \mathrm{Fe}^{2+} / \mathrm{mg}\right.$ extract) and maceration methanol (12.38 $\mathrm{mM} \mathrm{Fe}^{2+} / \mathrm{mg}$ extract) extracts were found to have stronger ferric reducing activity than the other extracts. The chloroform extract had the lowest ferric reducing activity. The results obtained from this study showed that both extraction techniques is the most suitable method to get the most powerful ferric reducing activity.

According to literature reviews, there are several studies on antioxidant activity of this plant. The antioxidant activity of the methanol extract obtained from maceration technical was examined using superoxide anion, hydrogen peroxide and DPPH methods. According to the results obtained study, methanol extract exhibited moderate superoxide anion $\left(\mathrm{IC}_{50}: 305.2 \mu \mathrm{g} / \mathrm{mL}\right)$, hydrogen peroxide $\left(\mathrm{IC}_{50}: 301.6 \mu \mathrm{g} / \mathrm{mL}\right)$, and DPPH $\left(\mathrm{IC}_{50}: 39 \mu \mathrm{g} / \mathrm{mL}\right)$ scavenging activity (Tatli et al., 2009). In another study, it was determined that plant's methanol extract from Soxhlet methods contained $87.36 \mathrm{mg} \mathrm{GAE} / \mathrm{g}$ extract of phenolic content and showed moderate phosphomolybdenum activity (163.47 $\mathrm{mg}$ ascorbic acid equivalent/g extract) and DPPH radical scavenging activity $\left(\mathrm{IC}_{50}: 23.48 \mu \mathrm{g} / \mathrm{mL}\right)$ (Albayrak et al., 2010).

In contrast to the above study, in our study, we examined the total flavonoids contents and antioxidant activity (DPPH, FRAP, ABTS) of four different extracts (Soxhlet petroleum ether, Soxhlet chloroform, Soxhlet methanol and maceration methanol extracts) obtained using different extraction methods. In addition, the effects of extraction methods/solvents on antioxidant activity were examined in this study. When the results obtained from the DPPH radical scavenging assay were compared with results of ours, it was found that Soxhlet methanol and maceration methanol extracts exhibited lower DPPH radical scavenging activity than above study. It was also found that maceration methanol and Soxhlet methanol extracts showed similar free radical activity in our study. 
TABLE II - The antioxidant activity of $H$. plicatum subsp. plicatum extracts

\begin{tabular}{|c|c|c|c|}
\hline Samples & $\begin{array}{c}\text { DPPH } \\
\left(\mathrm{IC}_{50}: \mathrm{mg} / \mathrm{mL}\right) \\
\end{array}$ & $\begin{array}{c}\text { ABTS } \\
\text { (mM trolox/mg extract) } \\
\end{array}$ & $\begin{array}{c}\text { FRAP assay } \\
\left(\mathrm{m} \mathrm{Fe}^{2+} / \mathrm{mg} \mathrm{extract}^{2}\right)\end{array}$ \\
\hline HPE & $0.12 \pm 0.03^{\mathrm{a}}$ & $42.27 \pm 0.04^{\mathrm{a}}$ & $9.63 \pm 0.004^{\mathrm{a}}$ \\
\hline $\mathrm{HC}$ & $0.24 \pm 0.02^{\mathrm{b}}$ & $38.29 \pm 0.06^{b}$ & $8.63 \pm 0.25^{\mathrm{b}}$ \\
\hline HSM & $0.11 \pm 0.01^{\mathrm{c}, \mathrm{a}}$ & $44.26 \pm 0.04^{\mathrm{c}}$ & $14.46 \pm 0.012^{c}$ \\
\hline HMM & $0.115 \pm 0.008^{\mathrm{d}, \mathrm{a}, \mathrm{c}}$ & $46.19 \pm 0.12^{\mathrm{d}}$ & $12.38 \pm 0.056^{\mathrm{d}}$ \\
\hline Ascorbic acid & $0.004 \pm \mathbf{0 . 0 0 2} 2^{\mathrm{e}}$ & & \\
\hline BHA & & $52.63 \pm 0.01^{\mathrm{e}}$ & $16.91 \pm 0.02^{\mathrm{e}}$ \\
\hline
\end{tabular}

Values are mean of triplicate determination $(\mathrm{n}=3) \pm{\text { standard deviation. Means with different superscripts }{ }^{(\mathrm{a}-\mathrm{e})} \text { are significantly }}$ different, $p<0.05$. HPE: Soxhlet petroleum ether extract; HC: Soxhlet chloroform extract HSM: Soxhlet methanol extract; HMM: Maceration methanol extract.

The results obtained from our study showed that Soxhlet methanol extraction technique is the most suitable method/ solvent to get the most powerful ferric reducing and DPPH radical scavenging activity. In addition, total flavonoid compounds analysis showed that the Soxhlet methanol extract exhibited the highest total flavonoid contents values. Flavonid compounds are known to have strong antioxidant effects. As a result, the strong antioxidant activity of this extract can be attributed to its contained higher amount of the flavonoid compounds.

\section{Urease inhibitory activity}

The results for the assessment of urease inhibitory activity of $H$. plicatum subsp. plicatum different extracts $(25 \mu \mathrm{g} / \mathrm{mL})$ were shown in Table III. The maceration methanol (13.13\%) extract exhibited the strongest antiurease activity. In the present study, maceration methanol methods/solvents were the most suitable solvents and methods to get the strongest anti-urease activity. According to this study, all the extracts had lower antiurease activity than thiourea (97.04\%). To the best of our knowledge, there have been no report in literature on the anti-urease activity of $H$. plicatum subsp. plicatum species. Therefore, the purpose of this study was to examine for the first time the anti-urease activity of this species's extracts obtained using different extraction methods and also to determine the most suitable extraction method and solvents. According to the results obtained from this study, the maceration method was found to have higher anti-urease activity over other methods.

\section{Antimicrobial activity}

In this study, the antimicrobial activity of the four different extracts from plant were investigated against $S$. aureus, $S$. epidermidis, E. coli, $P$. aeruginosa, $K$. pneumoniae, $P$. mirabilis, MRSA and C. albicans.
TABLE III - The urease inhibitory activity of different extracts from $H$. plicatum subsp. plicatum

\begin{tabular}{lc}
\hline Samples & $\begin{array}{c}\text { Urease inhibition (\%) } \\
(\mathbf{2 5} \boldsymbol{\mu g} / \mathbf{m L})\end{array}$ \\
\hline HPE & $6.35 \pm 1.5^{\mathrm{a}}$ \\
HC & $10.61 \pm 0.6^{\mathrm{b}}$ \\
HSM & $8.08 \pm 1.24^{\mathrm{c}}$ \\
HMM & $13.13 \pm 1.9^{\mathrm{d}}$ \\
Thiourea & $97.04 \pm 0.14^{\mathrm{e}}$ \\
\hline
\end{tabular}

Values are mean of triplicate determination $(\mathrm{n}=3) \pm$ standard deviation. Means with different superscripts ${ }^{(-\mathrm{a} e)}$ are significantly different, $p<0.05$. HPE: Soxhlet petroleum ether extract; HC: Soxhlet chloroform extract HSM: Soxhlet methanol extract; HMM: Maceration methanol extract

According to the results obtained from the antimicrobial activity test, Soxhlet methanol extract from plant showed moderate antibacterial and antifungal activity against $S$. aureus, $S$. epidermidis, MRSA and the yeast $C$. albicans while, no activity was observed against $E$. coli, $K$. pneumoniae, $P$. aeruginosa and $P$. mirabilis for any of the extracts. The petroleum ether extract obtained from Soxhlet method exhibited the significant antifungal activity against $C$. albicans. In addition, Soxhlet chloroform and maceration methanol extracts showed moderate activity against $C$. albicans, MRSA and C. albicans. According to this study, all the extracts showed lower antimicrobial activity than standard compounds such as cefuroxime-Na, ceftazidime, clotrimazole, oxacillin. When Soxhlet and maceration methods were compared between themselves, Soxhlet method was found to be more suitable for obtaining the significant antibacterial activity (Table IV).

To the best of our knowledge, there are some reports in literature on the antimicrobial activity of this 
TABLE IV - The antimicrobial activity of $H$. plicatum subsp. plicatum extracts

\begin{tabular}{|c|c|c|c|c|c|c|c|c|}
\hline $\begin{array}{l}\text { Extracts / } \\
\text { Standards }\end{array}$ & $\begin{array}{c}\text { Staphylococcus } \\
\text { aureus } \\
\text { ATCC } 6538\end{array}$ & $\begin{array}{c}\text { Meticillin } \\
\text { Resistant } \\
\text { Staphylococcus } \\
\text { aureus } \\
\text { ATCC } 33591 \\
\end{array}$ & $\begin{array}{l}\text { Staphylococcus } \\
\text { epidermidis } \\
\text { ATCC } 12228\end{array}$ & $\begin{array}{l}\text { Escherichia coli } \\
\text { ATCC } 8739\end{array}$ & $\begin{array}{c}\text { Klebsiella } \\
\text { pneumoniae } \\
\text { ATCC } 4352\end{array}$ & $\begin{array}{c}\text { Pseudomonas } \\
\text { aeruginosa } \\
\text { ATCC } 1539\end{array}$ & $\begin{array}{l}\text { Proteus mirabilis } \\
\text { ATCC } 14153\end{array}$ & $\begin{array}{c}\text { Candida } \\
\text { albicans } \\
\text { ATCC 10231 }\end{array}$ \\
\hline HPE & - & - & - & - & - & - & - & 312 \\
\hline $\mathrm{HC}$ & - & 1250 & & - & - & - & - & 625 \\
\hline Cefuroxime-Na & 1.2 & --- & 9.8 & 4.9 & 2.4 & 2.4 & - & --- \\
\hline Ceftazidime & --- & --- & --- & --- & 2.4 & --- & --- & --- \\
\hline Clotrimazole & --- & --- & --- & --- & --- & --- & 4.9 & --- \\
\hline Oxacillin & & $\geq 4 \mu \mathrm{g} / \mathrm{mL}$ & & & & & & \\
\hline
\end{tabular}

HPE: Soxhlet petroleum ether extract; HC: Soxhlet chloroform extract HSM: Soxhlet methanol extract; HMM: Maceration methanol extract. -: not active; --- : not tested; MIC: $\mathrm{Mg} / \mathrm{L}$.

species. The ethyl acetate, methanol, chloroform and acetone extracts from different parts (flowers, stem, leaves) of plant were tested in vitro against different bacterial species. According to the results obtained from the study, the ethyl acetate extracts from flowers, stem and leaves of plant have better antibacterial efficiency to Bacillus brevis FMC 3, B.megaterium DSM 32, B. subtilis IMG 22, B. subtilis var. niger ATCC 10, Escherichia coli DM, Listeria monocytogenes SCOTT A, Micrococcus luteus LA 2971, Mycobacterium smegmatus RUT, Staphylococcus aureus ATCC 25923, Straptococcus thermophilus, Yersinia enterocolitica than other extracts. All of the extracts from plant have shown no antibacterial efficiency to Corynebacterium xerosis (Erdogrul, Cakiroglu, Karaman, 2001). In another study, it was determined antimicrobial activity of that plant's methanol extract obtained from Soxhlet method and this extract was found to be active against Aeromonas hydrophila ATCC 7965, Klebsiella pneumoniae FMC 5, Pseudomonas aeruginosa ATCC 27853, Bacillus brevis FMC 3, B. cereus RSKK 863, B.subtilis ATCC 6633, Staphylococcus aureus ATCC 29213, Candida albicans ATCC 1223 and S.aureus ATCC 25923 (Albayrak et al., 2010). The methanol extract of this species showed antifungal activity against $C$. albicans similar to the our study (Albayrak et al., 2010). Unlike this study, methanol extracts did not show antibacterial activity against $K$. pneumoniae and P. aeruginosa in our study. However, when we compare the results of these studies, different results may be due to the use of different methods.

\section{Anticholinesterase activity}

The results for the assessment of cholinesterase inhibitory activity of $H$. plicatum subsp. plicatum different extracts $(500 \mu \mathrm{g} / \mathrm{mL})$ were shown in Table V. The Soxhlet methanol (58.51\%) extract exhibited the strongest anticholinesterase activity. Soxhlet petroleum ether extract did not show cholinesterase inhibitory activity. In the present study, Soxhlet methanol method/solvent were the most suitable solvent and method to get the strongest anticholinesterase activity. According to this study, all the extracts had lower anticholinesterase activity than galantamine $(88.14 \%)$. To the best of our knowledge, there have been no report in literature on the anticholinesterase activity of this species. Therefore, the purpose of this study was to examine for the first time the anticholinesterase activity of plant's extracts obtained using different extraction methods and also to determine the most suitable extraction method and solvents. According to the results obtained from this study, the Soxhlet method was found to have higher activity over other methods.

TABLE V - The anticholinesterase activity of different extracts from H. plicatum subsp. plicatum

\begin{tabular}{lc}
\hline Samples & $\begin{array}{c}\text { Enzyme inhibition (\%) } \\
\mathbf{( 5 0 0} \boldsymbol{\mu g} / \mathbf{m L})\end{array}$ \\
\hline HPE & - \\
HC & $1.28 \pm 0.24^{\mathrm{a}}$ \\
HSM & $58.51 \pm 0.85^{\mathrm{b}}$ \\
HMM & $42.10 \pm 0.79^{\mathrm{c}}$ \\
Galantamine $(200 \mu \mathrm{g} / \mathrm{mL})$ & $88.14 \pm 0.14^{\mathrm{d}}$ \\
\hline
\end{tabular}

Values are mean of triplicate determination $(n=3) \pm$ standard deviation. -: not active. Means with different superscripts ${ }^{(\mathrm{a}-\mathrm{d})}$ are significantly different, $p<0.05$. HPE: Soxhlet petroleum ether extract; HC: Soxhlet chloroform extract HSM: Soxhlet methanol extract; HMM: Maceration methanol extract. 


\section{In vivo evaluation of anti-inflammatory activity}

The injection of carrageenan showed a rapid increase in the paw volume, reaching its maximum $4 \mathrm{~h}$. postinjection (Vazquez et al., 2015). Indomethacin $(5 \mathrm{mg} / \mathrm{kg}$ ) indicated maximum anti-inflammatory effect at 4 hours after carrageenan injection by $89.73 \%$ (Table VI, $p<0.001$ ). HMM demonstrated a more prominent and intensive antiinflammatory effect at first hour after carrageenan injection with $62.06 \%$ and at fourth hours with $66.58 \%$ of inhibitive capacity in the altered edema size compared to HSM. However, HSM's inhibitory effect reached maximum by $77.94 \%$ in second hour $(p<0.001)$ and it was more intensive compared to HMM (Table VI, $p<0.01$ ). Carrageenaninduced edema is widely used as an experimental animal model in evaluation of acute inflammation and is believed to be biphasic, of which the first phase is mediated by the release of histamine and 5-hydroxytryptamine followed by kinin release and then prostaglandin in the later phase (Chaulya, Halda, Mukherjee, 2012; Alcaraz, Jimenez, 1988). Acute single-dose of HMM and HSM significantly reduced rat paw edema volume, especially at 2 hours after carrageenan injection. Some phenolic compounds have been reported to reveal inhibition of histamine release in mast cells, which is responsible for early phase of inflammation induced by carrageenan (Jabeur et al., 2017). Thus, plant's acute anti-inflammatory effects may be based upon its phenolic composition. Consequently, phenolic compounds are possible to be the effective components, which trigger the anti-inflammatory action, but further investigations are needed to determine precise mechanisms. There have been no study on anti-inflammatory activities of maceration and Soxhlet methanol extracts from the aerial parts of plant. In this study, anti-inflammatory activity of extracts was examined for the first time and according to the obtained results, both extracts from plant showed strong anti-inflammatory activity $(p<0.001)$.

\section{Analysis of phenolic compounds}

In this study, phenolic compounds in Soxhlet and maceration methanol extracts were analysed because these extracts showed strong antioxidant, anti-urease, antimicrobial, anti-inflammatory and anticholinesterase activity than other extracts. The phenolic compounds were identified as chlorogenic acid, dicaffeoylquinic acid, luteolin, luteolin-7- $O$-glucoside, naringenin- $O$-hexoside and isoquercitrin in methanol extracts by HPLC-DAD and ESI-Q-TOF LC/MS (Table VII). To the best of our knowledge, there are some reports in literature on the chemical contents of this species. In a study, apigenin, $\beta$-sitosterol 3-O- $\beta$-D-glikopiranozit, helichrysin A, helichrysin $\mathrm{B}$, astragalin, isosalipurposit compounds were isolated from the plant's methanol extract (Demir et al., 2009). In another study, it was analyzed that the plant methanol extract contained caffeic acid, chlorogenic

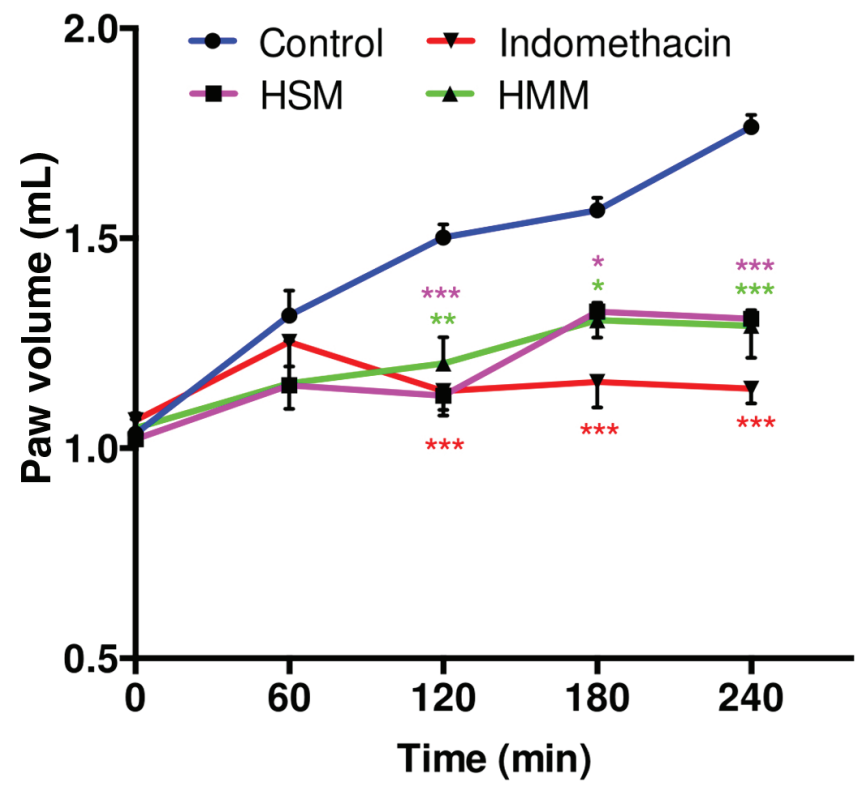

FIGURE 1 - Anti-inflammatory effect of Soxhlet methanol and maceration methanol extracts of plant on carrageenan-induced paw edema. Values are mean of triplicate determination and expresses as Mean \pm SEM (Standard error mean); values are calculated using two-way ANOVA followed by Tukey posttests; $* * * p<0.001, * * p<0.01$ and $* p<0.05$ when compared to control group; $\mathrm{n}=6$. HSM: Soxhlet methanol extract; HMM: maceration methanol extract.

TABLE VI - Results of \% inhibition of paw edema in extracts from H. plicatum subsp. plicatum on carrageenan-induced paw edema $(n=6)$

\begin{tabular}{lllll}
\hline Treatment & $\mathbf{6 0}$ min & $\mathbf{1 2 0}$ min & $\mathbf{1 8 0}$ min & $\mathbf{2 4 0}$ min \\
\hline HSM $(250 \mathrm{mg} / \mathrm{kg})$ & $54.61 \%$ & $77.94 \%$ & $43.05 \%$ & $60.82 \%$ \\
$\mathrm{HMM}(250 \mathrm{mg} / \mathrm{kg})$ & $62.06 \%$ & $67.02 \%$ & $51.69 \%$ & $66.58 \%$ \\
Indomethacin & $34.04 \%$ & $85.01 \%$ & $82.89 \%$ & $89.73 \%$ \\
\hline
\end{tabular}

HSM: Soxhlet methanol extract; HMM: Maceration methanol extract. Values are mean of triplicate determination. 
TABLE VII - Identification of phenolic compounds in H. plicatum subsp. plicatum

\begin{tabular}{lccc}
\hline Compounds & Rt (min) & {$[\mathbf{M}-\mathbf{H}]^{-}$} & $\begin{array}{c}\boldsymbol{m} / \mathbf{z} \text { Fragment(s) } \\
\text { (targeted MS/MS mode) }\end{array}$ \\
\hline Chlorogenic acid & 10.991 & 353.0913 & 191 (M-caffeoyl), 179 (M- quinic) \\
Dicaffeoylquinic acid & 19.099 & 515.113 & $353,284,173,135$ \\
Luteolin & 23.594 & 285.0368 & $217,199,175,151,133$ \\
Luteolin-7- $O$-glucoside & 17.019 & 447.0876 & 285 \\
Naringenin- $O$-hexoside & 13.447 & 433.1218 & $271,151,119,65$ \\
Isoquercitrin & 13.692 & $577.0977(\mathrm{M}+\mathrm{TFA})$ & 301 \\
\hline
\end{tabular}

acid, $p$-coumaric acid, $p$-hydroxybenzoic acid, apigenin, apigenin-7-glucoside, hesperidin, luteolin, and naringenin by using HPLC-DAD. In addition, according to obtained results, in methanol extract from flowers, leaves, and stembarks identified the chlorogenic acid, quercetin and rutin compounds as the major compound (Albayrak et al., 2010; Kolayli et al., 2010). Unlike the above study, in our study, the effects of extraction methods and solvents on biological activities were examined. Then, the phenolic compounds in Soxhlet and maceration methanol extracts were analysed by HPLC-DAD and LC-MS/MS. As a result of this study, dicaffeoylquinic acid, luteolin-7-O-glucoside, naringenin$O$-hexoside and isoquercitrin were analysed for the first time in methanol extracts from plant's aerial parts.

It is important to select an extraction technique that is appropriate for the standardization of plant products and phytochemical analysis. When different extraction methods and different solvents are used, the different compounds are obtained and in this case the biological activity of the plants changes (Azwanida, 2015). Therefore, in this study, different extraction methods and solvents were selected. The effect of the methanol solvent on biological activities was found to be higher than that of other solvents. It was also observed that the extraction method had an important determining factor on activity results. In our investigation, we can get different results even if we use the same solvent since the amounts of bioactive compounds could be changed by the different extraction methods. However, in our study Soxhlet and maceration methods showed biological activity very close to each other. In addition, it was found that the methanol extracts obtained using both methods contained similar phenolic compounds.

Phenolic compounds (flavonoids, phenolic acids etc.) are known to exhibit strong biological activity (antioxidant, antimicrobial, anticancer, anti-inflammatory etc.) Also, the researchers use alcohols or aqueous alcohol mixtures for extracting of the polar flavonoids and glycosides (Li et al., 2014; Beer et al., 2002; Anantharaju et al., 2016). In this study, parallel to the literatüre, it was determined that the plant exhibited strong biological activity due to its the phenolic compounds. Although both extracts contain similar phenolic compounds, there is a small difference between results and this difference is thought to be caused by change in the amount of the same or similar substances extracting into the solution.

\section{CONCLUSION}

In this study, we investigated the effect of extraction methods on biological activity and found that Soxhlet and maceration methanol extracts showed biological activity (in vitro and in vivo) close to each other. It was also found that antioxidant active compounds play an important role in anti-inflammatory activity. The phenolic compounds responsible for biological activity were analyzed by HPLC-DAD and LC-MS/MS and chlorogenic acid, dicaffeoylquinic acid, luteolin, luteolin-7-O-glucoside, naringenin- $O$-hexoside and isoquercitrin compounds were found to be in the Soxhlet and maceration methanol extracts. Therefore, these extracts can be used as natural antioxidants, antimicrobial, anticholinesterase, antiinflammatory and anti-urease agents in the future for food and pharmaceutical industry.

\section{CONFLICT OF INTEREST}

The authors declare that there is no conflict of interest regarding the publication and dissemination of the information provided herein.

\section{REFERENCES}

Albayrak S, Aksoy A, Sagdic O, Hamzaoglu E. Compositions, antioxidant and antimicrobial activities of Helichrysum (Asteraceae) species collected from Turkey. Food Chem. 2010;119(2010):114-122. 
Alcaraz MJ, Jimenez MI. Flavonoid as anti-inflammatory agents. Fitoterapia. 1988;59: 25-38.

Anantharaju PG, Gowda PC, Vimalambile MG, Madhunapantula $\mathrm{SV}$. An overview on the role of dietary phenolics for the treatment of cancers. Nutrition J. 2016;15(99):2-16.

Aslan M, Katırcıoğlu H, Orhan I, Atıcı T, Sezik E. Antibacterial potential of the capitula of eight anatolian Helichrysum species. Turkish J Pharm Sci. 2007;4(2):71-77.

Azwanida NN. A review on the extraction methods use in medicinal plants, principle, strength and limitation. Med Aromat Plants. 2015;4(3):1-6.

Bayir Y, Halici Z, Keles MS, Colak S, Cakir A, Kaya Y, Akcay F. Helichrysum plicatum DC. subsp. plicatum extract as a preventive agent in experimentally induced urolithiasis model. J Ethnopharmacol. 2011;138(2):408-414.

Beer D, Joubert E, Gelderblom WCA, Manley M. Phenolic compounds: a review of their possible role as in vivo antioxidants of wine. S Afr J Enol Vitic. 2002; 23(2):48-61.

Benzie IF, Strain JJ. The ferric reducing ability of plasma (FRAP) as a measure of "antioxidant power": the FRAP assay. Anal Biochem. 1996;239(1):70-76.

Chaulya NC, Halda PK, Mukherjee A. Anti-inflammatory and analgesic activity of methanol extracts of Cyperus tegetum Roxb. Rhizome. J Pharma Sci Tech. 2012;1(2):27-29.

Clinical and Laboratory Standards Institute (CLSI). Methods for dilution antimicrobial susceptibility tests for bacteria that grow aerobically: Approved standard M7-A5. Wayne, PA: CLSI; 2006.

Clinical and Laboratory Standards Institute (CLSI). Reference method for broth dilution antifungal susceptbility testing of yeasts; Approved standart M27-A NCCLS, Wayne, Pennsylvania; 2000.

Davis PH, Mill RR, Tan K. Flora of Turkey and East Aeagen Islands. v. X. Edinburgh: Edinburgh University Press; 1988, p. 159-160.

Davis PH. Flora of Turkey and East Aeagen Islands v. V. Edinburgh: Edinburgh University Press; 1975.
Demir A, Taban BM, Aslan M, Yeşilada E, Aytaç SA. Antimicrobial effect of Helichrysum plicatum subsp. plicatum. Pharma Biol. 2009;47(4): 289-297.

Denys JC. Antioxidant properties do spices, herbs and other sources. New York: Springer Science-Business Media; 2013, p. 3-6.

Ellman GL, Courtney KD, Andress V, Featherstone RM. A new and rapid colorimetric determination of acetylcholinesterase activity. Biochem Pharmacol. 1961;7(2):88-95.

Erdogrul OT, Cakiroglu E, Karaman S. Antibacterial activities of Helichrysum plicatum subsp. plicatum extracts. Sciences. 2001;1(3):176-178.

Erik S. Helichrysum Gaertner in: Güner A, Özhatay N, Ekim T, Başer KHC. Flora of Turkey and East Aeagen Islands. v XI. Edinburgh: Edinburgh University Press; 2000, p. 153-154.

Ghous T, Akhtar K, Nasim FUH, Choudhry MA. Screening of selected medicinal plants for urease inhibitory activity. BLM. 2010;2:64-69.

Halpine SM. An improved dye and lake pigment analysis method for high-performance liquid chromatography and diodearray detector. Stud Conserv. 1996;41:76-94.

Jabeur I, Martins N, Barros L, Calhelha RC, Vaz J, Achour L, Santos-Buelga C, Ferreira ICFR. Contribution of the phenolic composition to the antioxidant, anti-inflammatory and antitumor potential of Equisetum giganteum L. and Tilia platyphyllos scop. Food Funct. 2017;8(3):975-984.

Kolaylı S, Şahin H, Ulusoy E, Tarhan Ö. Phenolic composition and antioxidant capacities of Helichrysum plicatum. Hacettepe J Biol.Chem. 2010;38(4):269-276.

Kupicha FK. Helichrysum Gaertner in: Davis PH (ed). Flora of Turkey and East Aeagen Islands. v. V. Edinburgh: Edinburgh University Press; 1975, p. 80-97.

Li AN, Li S, Zhang YJ, Xu XR, Chen YM, Li HB. Resources and biological activities of natural polyphenols. Nutrients. 2014;6(12):6020-6047.

Murugan, R, Parimelazhagan T. Comparative evaluation of different extraction methods for antioxidant and antiinflammatory properties from Osbeckia parvifolia Arn. An in vitro approach. J King Saud Univ. 2014;26(4):267-275. 
Parimelazhagan T. Pharmacological assays of plant based natural products. Switzerland: Springer İnternational Publishing; 2016; p. 100-102.

Perez C, Pauli M, Bazerque P. An Antibiotic assay by the agarwell diffusion method. Acta Bio Med.Experi. 1990;15:113-115.

Re R. Pellegrini N, Proteggente A, Pannala A, Yang M, Evans CR. Antioxidant activity applying an improved ABTS radical cation decolorization assay. Free Radical Bio Med. 1999;26(910):1231-1237.

Samatha T, Shyamsundarachary R, Srinıvas P, Swamy NR. Quantification of total phenolic and total flavonoid contents in extracts of Oroxylum indicum L. Kurtz. Asian J Pharm Clin Res. 2012;5(2012):177-187.

Selcuk SS, Birteksöz AS. Flavonoids of Helichrysum chasmolycicum and its antioxidant and antimicrobial activities. S Afr J Bot. 2011;77(1):170-174.

Sezik M, Aslan M, Orhan DD, Erdemoglu E, Pekcan M, Mungan $\mathrm{T}$, Sezik E. Improved metabolic control and hepatic oxidative biomarkers with the periconception use of Helichrysum plicatum ssp. plicatum. J Obstet Gynaecol. 2010;30(2):127-131.
Suzgec S, Meriçli AH, Houghton PJ, Çubukçu B. Flavonoids of Helichrysum compactum and their antioxidant and antibacterial activity. Fitoterapia. 2005;76(2):269-272.

Tatlı I, Sahpaz S, Akkol EK, Nizard FM, Gressier B, Ezer N, Bailleul F. Antioxidant, anti inflammatory, and antinociceptive activities of Turkish medicinal plants. Pharma Biol. 2009;47(9):916-921.

Vazquez E, Navarro M, Salazar Y, Crespo G, Bruges G, Osorio C. et al. Systemic changes following carrageenan-induced paw inflammation in rats. Inflammat Res. 2015;64(5):333-342.

Wei F, Jinglou C, Yaling C, Yongfang L, Liming C, Lei P. Antioxidant, free radical scavenging, anti-inflammatoryand hepatoprotective potential of the extract from Parathelypteris nipponica (Franch.etSav.) Ching. J Ethnopharmacol. 2010;130(3):521-28.

Yeşil Y, Akalın E. Folk medicinal plants in kürecik area (Akçadağ/malatya-Turkey). Turk J Pharm Sci. 2009;6:207-220.

Received for publication on $30^{\text {th }}$ April 2018 Accepted for publication on $18^{\text {th }}$ December 2018 